\title{
Increased NPN
}

National Cancer Institute

\section{Source}

National Cancer Institute. Increased NPN. NCI Thesaurus. Code C34851.

A laboratory test result indicating abnormally high concentration of non-protein nitrogen

in the blood. 